\title{
Concentration Gradient Pd-Ir-Ni/C Electrocatalyst with Enhanced Activity and Methanol Tolerance for Oxygen Reduction Reaction in Acidic Medium
}

\author{
Esubalew Meku, Chunyu Du*, Yajing Wang, Lei Du, Yongrong Sun, Fanpeng Kong, Geping \\ Yin
}

School of Chemical Engineering and Technology, Harbin Institute of Technology, Harbin 150001, China

Corresponding author:

Chunyu Du

Tel: +86-451-86403961

Fax: +86-451-86418616

E-mail: cydu@hit.edu.cn 


\begin{abstract}
This study demonstrates a concept of concentration gradient (CG) Pd-Ir-Ni/C electrocatalyst consisting of IrNi alloy core, concentration gradient IrPd layer and Pd surface for the oxygen reduction reaction (ORR), which is synthesized by a facile sequential polyol method without any additional surfactant. The CG Pd-Ir-Ni/C electrocatalyst is characterized by X-ray diffraction, transmission electron microscopy and X-ray photoelectron spectroscopy. It is found that the PdIr-Ni nanoparticles with a mean diameter of $5.8 \pm 1.5 \mathrm{~nm}$ are uniformly distributed on the carbon support. These Pd-Ir-Ni nanoparticles possess a certain degree of Pd alloying through the spontaneous replacement reaction, and concentration gradient IrPd shell with Pd-rich surface. The ORR polarization measurement of the CG Pd-Ir-Ni/C catalyst illustrates a mass activity of 5.6 and 9.9 times that of $\mathrm{Pd} / \mathrm{C}$ catalyst at $0.80 \mathrm{~V}$ and $0.7 \mathrm{~V}$, respectively. Moreover, this catalyst exhibits a better ORR selectivity than commercial $\mathrm{Pt} / \mathrm{C}$ catalyst in the presence of methanol. The enhanced electrocatalytic activity is mainly attributed to the optimal compressive lattice strain of surface $\mathrm{Pd}$ induced by the underlying concentration gradient layer. Our work provides a highly potential strategy to develop high performance and low cost electrocatalytic materials for fuel cells.
\end{abstract}

Keywords: Electrocatalyst, oxygen reduction reaction, concentration gradient core-shell, palladium-iridium-nickel, methanol tolerance. 


\section{Introduction}

The oxygen reduction reaction (ORR) is a ubiquitous reaction and plays a pivotal role in the electrochemical energy conversion devices, such as fuel cells and metal air batteries [1,2]. The catalysts of choice for the desired ORR process are generally platinum and its alloys [3-6]. However, the scarcity of platinum in resources leads to its soaring price and thus the rather high cost of corresponding devices [7,8]. Moreover, platinum is susceptible to the poisoning of impurities, such as the sulfides in the air or the fuels crossed over from the anode, decreasing the energy-conversion efficiency and long-term reliability of devices $[9,10]$. It is therefore in urgent need to develop non-platinum ORR catalysts with low cost, high activity and enhanced tolerance to impurities.

In this regard, $\mathrm{Pd}$ is considered as a promising alternative ORR catalyst to significantly reduce the cost because of its high abundance and similar properties with Pt such as the same crystalline structure and close lattice parameters [11,12]. Unfortunately, the intrinsic catalytic activity of $\mathrm{Pd}$ for the ORR is still lower than that of $\mathrm{Pt}[13,14]$. The common approach to improving the ORR activity of $\mathrm{Pd}$ is alloying it with transition metals to form Pd-based binary or ternary alloys [15-22], which show greatly improved ORR activity. For instance, Manthiram et al investigated carbon supported $\mathrm{Pd}-\mathrm{Ni}$ alloy electrocatalysts with different $\mathrm{Pd} / \mathrm{Ni}$ atomic ratios, demonstrating that the $\mathrm{Pd}_{80} \mathrm{Ni}_{20} / \mathrm{C}$ catalyst had enhanced ORR activity and methanol tolerance [21]; Wang et al synthesized carbon supported $\mathrm{Pd}_{3} \mathrm{Co}\left(\mathrm{Pd}_{3} \mathrm{Co} / \mathrm{C}\right)$ catalyst with the ORR activity comparable to commercial $\mathrm{Pt} / \mathrm{C}$ [22]. Nevertheless, the Pd-based alloys still require a large amount of $\mathrm{Pd}$, leading to relatively high cost despite the lower price of Pd. Most importantly, the leaching of less stable transition metals from Pd-based alloys during the long-term operation deteriorates the $\mathrm{Pd}$ alloy catalysts and causes contamination by the leached ions [23,24]. As a 
result, the design of inexpensive Pd-based electrocatalysts with enhanced ORR activity, structural stability and tolerance to impurities is still a critical technological challenge [25].

Recently, core-shell nanoparticles (NPs) have attracted much attention as highly efficient electrocatalysts because their unique composition, structure and particle size can be adjusted in a controllable way [26-30]. For example, Adzic and co-workers utilized underpotential deposition and galvanic displacement reactions to prepare the $\mathrm{Pd} / \mathrm{Pt}$ and $\mathrm{Pd}_{9} \mathrm{Au}_{1} / \mathrm{Pt}$ core-shell NPs [31], which exhibited greatly enhanced catalytic activity towards the ORR in acidic media. Our group synthesized the $\mathrm{Au} / \mathrm{Pd}$ core-shell NPs by a three-phase-transfer approach, which showed much high activity and stability for the methanol oxidation reaction in alkaline media [32]. For coreshell electrocatalysts, it has been proved that the geometric and electronic characteristics and thus the electrocatalytic activity of the shells depend highly on the cores [33,34]. Meanwhile, the shells might be destroyed so that the core elements readily suffer from corrosion during the longterm operation, leading to the low stability of core-shell electrocatalysts, which is mainly determined by the compatibility between cores and shells $[35,36]$.

We herein present a novel concentration gradient (CG) Pd-Ir-Ni nanostructure, whose composition varies from NiIr core to $\mathrm{Pd}$ surface via IrPd transition layer for the first time (Scheme 1). The carbon supported CG Pd-Ir-Ni NPs (Pd-Ir-Ni/C) are synthesized by a facile polyol method. Briefly, microwave heating of a mixture of $\mathrm{Ir}$ and $\mathrm{Ni}$ precursors in ethylene glycol solvent generates the IrNi alloy NPs, onto which PdIr shell with CG Pd content is coated by the displacement and reduction reactions at high temperatures, forming the CG Pd-Ir-Ni nanostructure. The structural and electrochemical properties of the CG Pd-Ir-Ni/C catalyst are analyzed using X-ray diffraction (XRD), transmission electron microscopy (TEM) equipped with energy dispersive X-ray spectroscopy (EDS), X-ray photoelectron spectroscopy (XPS), cyclic 
voltammetry $(\mathrm{CV})$ and rotating disc electrode (RDE) techniques. This CG Pd-Ir-Ni/C catalyst maintains the advantage of low cost for conventional core-shell structures. Moreover, its electrocatalytic activity is tunable by the underlying alloy layers containing $\mathrm{Ni}$ and/or Ir, which have been confirmed to be able to promote the ORR activity of Pd-based alloys [37-39]. Also, the compatibility between core and shell is improved by the transition layer, which will be beneficial to the long-term stability of the nanostructured catalyst. The CG Pd-Ir-Ni/C electrocatalyst shows significantly enhanced ORR activity and methanol tolerance, which presents a promising electrocatalytic material for the ORR and other electrochemical applications.

\section{Experimental}

\subsection{Synthesis}

The concentration gradient (CG) Pd-Ir-Ni/C electrocatalyst was facilely synthesized by a modified polyol method in two sequential steps. Initially, an equimolar ratio of iridium (Ir) and nickel (Ni) precursors $\left(\mathrm{H}_{2} \mathrm{IrCl}_{6} \cdot 6 \mathrm{H}_{2} \mathrm{O}\right.$ and $\left.\mathrm{NiCl}_{2} \cdot 6 \mathrm{H}_{2} \mathrm{O}\right)$ were ultrasonically mixed with a suspension of Vulcan XC-72R carbon in ethylene glycol (EG) for 30 min and magnetically stirred for $1 \mathrm{~h}$. The $\mathrm{pH}$ of the mixture was then adjusted to 10.0 using $0.5 \mathrm{M} \mathrm{NaOH}$ in EG solution. After another $2 \mathrm{~h}$ of stirring, the mixture was purged with Ar gas for $30 \mathrm{~min}$ to remove the dissolved oxygen, heated in a microwave reactor for $75 \mathrm{~s}$, cooled down to room temperature and stirred overnight. The resulted $\mathrm{IrNi} / \mathrm{C}$ sample was collected after centrifugation, thorough washing with ultrapure water and ethanol, and drying in a vacuum oven at $60{ }^{\circ} \mathrm{C}$ overnight.

$50 \mathrm{mg}$ of the as-prepared $\mathrm{IrNi} / \mathrm{C}$ sample was then dispersed in $\mathrm{EG}$, into which an $\mathrm{EG}$ solution of $\mathrm{PdCl}_{2}(\mathrm{Pd}: \mathrm{Ir}=3: 1)$ was dropwise added under stirring and purging with $\mathrm{Ar}$ gas. The $\mathrm{pH}$ of the resulting suspension was subsequently adjusted to 10.0 by adding $0.5 \mathrm{M} \mathrm{NaOH}$ in EG 
solution. After that, the suspension was heated in oil bath at $110{ }^{\circ} \mathrm{C}$ for $3 \mathrm{~h}$ under vigorous stirring and Ar gas atmosphere. The CG Pd-Ir-Ni/C catalyst with $20 \mathrm{wt} \% \mathrm{Pd}$ metal loading was finally obtained after centrifugation, washing several times with ultrapure water and ethanol, and drying in a vacuum oven at $60{ }^{\circ} \mathrm{C}$ overnight. For comparison, $\mathrm{Pd} / \mathrm{C}, \mathrm{Pt} / \mathrm{C}$, and $\mathrm{Ir} / \mathrm{C}$ catalysts with the same metal loading were also prepared using the microwave-assisted polyol method under the same conditions.

\subsection{Physical characterization}

The structural characterization was carried out by Panalytical Empyrean XRD system using $\mathrm{Cu} \mathrm{K \alpha}(\lambda=1.5406 \AA) \mathrm{X}$-ray source operating at $40 \mathrm{kV}$. The morphology and particle size distribution of the catalysts were characterized using JEM 1200EX TEM instrument operating at $100 \mathrm{kV}$. The high resolution TEM (HRTEM) and high angle annular dark field scanning TEM (HAADF-STEM) images of the catalysts were collected by the FEI TECHNAI G2 F-30 TEM instrument at an accelerating voltage of $300 \mathrm{kV}$, by which the EDS results were also obtained. The surface composition and electronic states of the samples were determined by XPS using Thermo 250XI instrument with a monochromatic $\mathrm{Al} \mathrm{K} \alpha$ radiation $(\lambda v=1486.6 \mathrm{eV})$.

\subsection{Electrochemical tests}

The electrochemical tests were carried out by an electrochemical work station (CHI 604d) using a conventional three-electrode cell. A Pt-foil, an $\mathrm{Hg} / \mathrm{Hg}_{2} \mathrm{SO}_{4} / \mathrm{SO}_{4}{ }^{2-}$ (sat.) and a catalyst modified glassy carbon (GC) electrodes were used as counter, reference and working electrodes, respectively. The catalyst ink was prepared by ultrasonicating $5 \mathrm{mg}$ of the catalyst powder in 3 $\mathrm{mL}$ of de-ionized water, $2 \mathrm{~mL}$ of isopropyl alcohol and $5 \mu \mathrm{L}$ of $5 \mathrm{wt} \%$ Nafion (Dupont). $15 \mu \mathrm{L}$ of the homogeneous catalyst ink was then drop-casted onto the $\mathrm{GC}$ working electrode $(5 \mathrm{~mm}$ diameter) and allowed to dry in air at room temperature to form a thin film of the catalyst with a 
metal loading of $15.3 \mu \mathrm{g} \mathrm{cm}^{-2}$. The $\mathrm{CV}$ curves of the catalysts were recorded in the potential range between $0.05 \mathrm{~V}$ and $1.0 \mathrm{~V}$ at a scan rate of $50 \mathrm{mV} \mathrm{s}^{-1}$ in $\mathrm{N}_{2}$ saturated $0.1 \mathrm{M} \mathrm{HClO}_{4}$ solution. The ORR polarization was conducted on a rotating disc electrode (RDE) in $\mathrm{O}_{2}$ saturated $0.1 \mathrm{M}$ $\mathrm{HClO}_{4}$ solution at a sweep rate of $5 \mathrm{mV} \mathrm{s}^{-1}$ from $1.0 \mathrm{~V}$ and $0.0 \mathrm{~V}$. The methanol tolerance of the CG Pd-Ir-Ni/C and Pt/C catalysts was evaluated by the linear potential sweeping from $1.0 \mathrm{~V}$ to $0.0 \mathrm{~V}$ in $\mathrm{O}_{2}$ saturated $0.1 \mathrm{M} \mathrm{HClO}_{4}$ and $1.0 \mathrm{M} \mathrm{CH}_{3} \mathrm{OH}$ solution at a scan rate of $5 \mathrm{mV} \mathrm{s}^{-1}$ and a rotation speed of $1600 \mathrm{rpm}$. The accelerated durability test (ADT) of the CG Pd-Ir-Ni/C nanostructure and $\mathrm{Pd} / \mathrm{C}$ catalyst was performed by potential cycling between 0.6 and $1.1 \mathrm{~V}$ in $\mathrm{N}_{2}$ saturated $0.1 \mathrm{M} \mathrm{HClO}_{4}$ solution at scan rate of $50 \mathrm{mV} \mathrm{s}^{-1}$ for 1000 potential cycles. Prior to the electrochemical measurements, the working electrodes were activated between $0.05 \mathrm{~V}$ and $1.0 \mathrm{~V}$ in $\mathrm{N}_{2}$ saturated $0.1 \mathrm{M} \mathrm{HClO}_{4}$ solution for 50 cycles at a scan rate of $50 \mathrm{mV} \mathrm{s}{ }^{-1}$. All the electrochemical measurements were carried out at room temperature and all the potentials were reported with respect to the reversible hydrogen electrode (RHE).

\section{Results and discussion}

Fig. 1a shows XRD patterns of the as-prepared catalysts. The diffraction peak at about $2 \theta=$ $25^{\circ}$ for all the samples corresponds to the (002) plane of carbon support. The peak at $41.2^{\circ}$ for $\mathrm{Ir} / \mathrm{C}$ catalyst is indexed to the $\operatorname{Ir}(111)$ plane, which is broadened probably due to the small size of the Ir NPs. The (111) peak for IrNi/C catalyst is located between that for pure Ir (PDF \#870715) and pure Ni (PDF \#70-0989), suggesting the formation of the IrNi alloy. For the CG Pd-Ir$\mathrm{Ni} / \mathrm{C}$ catalyst, the diffraction peaks at $40.3^{\circ}, 46.8^{\circ}, 68.3^{\circ}$ and $82.2^{\circ}$ are characteristics of face centered cubic (fcc) Pd crystal (PDF \# 87-0643), which correspond to the (111), (200), (220) and (311) planes, respectively. From the enlarged (111) peak of Pd/C, IrNi/C and CG Pd-Ir-Ni/C catalysts (Fig. 1b), it is clearly observed that the peak position of CG Pd-Ir-Ni/C catalyst shifts 
positively compared with that of $\mathrm{Pd} / \mathrm{C}$, which suggests that $\mathrm{Pd}$ might deposit on the preformed IrNi NPs and some degree of Pd alloying occurs $[22,38]$. The formation of Pd alloy could be due to the spontaneous replacement of surface $\mathrm{Ni}$ or Ir atoms by $\mathrm{Pd}$ atoms via the reaction of $\mathrm{Pd}^{2+}$ and the IrNi alloy. This spontaneous replacement is feasible since the standard potential of $\mathrm{Pd}^{2+} / \mathrm{Pd}$ couple $(+0.915 \mathrm{~V}$ vs. $\mathrm{RHE})$ is more positive than that of $\mathrm{Ni}^{2+} / \mathrm{Ni}(-0.257 \mathrm{~V}$ vs. RHE) and $\mathrm{Ir}^{4+} / \mathrm{Ir}(+0.835 \mathrm{~V})$ couples [40]. Moreover, the replacement between $\left[\mathrm{PdCl}_{4}\right]^{2-}$ and $\mathrm{Ni}$ is more favorable because the standard potential of $\mathrm{Ir}^{4+} / \mathrm{Ir}(+0.835 \mathrm{~V})$ is higher than that $\mathrm{of}^{2 i^{2+}} / \mathrm{Ni}(-$ $0.257 \mathrm{~V}$ vs. RHE). Therefore, PdIr alloy is more likely to form on the IrNi alloy NPs. Table 1 presents the lattice parameters of $\mathrm{Pd} / \mathrm{C}, \mathrm{IrNi} / \mathrm{C}$ and $\mathrm{CG}$ Pd-Ir-Ni/C catalysts, estimated from the (111) diffraction peak, which decrease in the sequence of Pd/C > CG Pd-Ir-Ni/C $>\operatorname{IrNi} / \mathrm{C}$, demonstrating the compressive lattice strain of the CG Pd-Ir-Ni/C catalyst induced by the smaller IrNi core $[41,42]$. The crystallite size of the as-prepared Pd/C, IrNi/C and CG Pd-Ir-Ni/C catalysts, calculated using the Debye-Scherrer equation [43], is $8.4 \mathrm{~nm}, 4.6 \mathrm{~nm}$ and $6.7 \mathrm{~nm}$, respectively. The smaller size of $\mathrm{IrNi} / \mathrm{C}$ catalyst than $\mathrm{Pd} / \mathrm{C}$ should be mainly due to the less particle aggregation or growth since alloying of IrNi reduces the surface energy [38]. The larger size of CG Pd-Ir-Ni/C than $\mathrm{IrNi} / \mathrm{C}$ indicates that the $\mathrm{Pd}$ atoms, which are obtained by the reduction of EG at high temperature, coat on the surface of IrNi alloy seed NPs, rather than selfnucleate as separate Pd clusters [44]. Besides, the replacement of smaller Ni atoms by larger Pd atoms also contributes to the increase in the particle size of CG Pd-Ir-Ni/C catalyst [45].

The morphology and particle size distribution of the as-prepared $\mathrm{Pd} / \mathrm{C}, \mathrm{IrNi} / \mathrm{C}$ and CG PdIr-Ni/C catalysts are characterized by TEM and shown in Fig. 2. In all the samples, the metal NPs are homogenously distributed on the carbon support. The average particle size, calculated from randomly selected 150 nanoparticles, is $7.2 \pm 1.8 \mathrm{~nm}, 4.2 \pm 1.1 \mathrm{~nm}$ and $5.8 \pm 1.5 \mathrm{~nm}$ for 
$\mathrm{Pd} / \mathrm{C}, \mathrm{IrNi} / \mathrm{C}$ and $\mathrm{CG} \mathrm{Pd}-\mathrm{Ir}-\mathrm{Ni} / \mathrm{C}$ catalysts, respectively. These particle sizes are consistent with the XRD result, although they are a little smaller than the XRD result, because XRD generally provides volume-weighted measurements and tends to overestimate the geometric particle size [46]. A smaller standard deviation of the particle size is observed for $\mathrm{IrNi} / \mathrm{C}$ and $\mathrm{CG} \mathrm{Pd}-\mathrm{Ir}-\mathrm{Ni} / \mathrm{C}$ catalysts, demonstrating their better dispersion.

The HRTEM images (Fig. 3) demonstrate the crystalline nature of Pd/C and CG Pd-Ir-Ni/C catalysts. The distance between two adjacent lattice planes in the inner region of CG Pd-Ir-Ni/C catalyst is estimated to be $0.214 \mathrm{~nm}$, which is indexed to the (111) plane of the IrNi core. This interplanar distance is smaller than that of pure $\operatorname{Ir}(0.218 \mathrm{~nm})$ [47], confirming the lattice contraction as a result of alloying between Ir and $\mathrm{Ni}$. The outer layer presents the lattice plane distance of $0.223 \mathrm{~nm}$ assigned to the Pd (111) plane (PDF \# 87-0643), which is smaller than that of pure $\mathrm{Pd} / \mathrm{C}$ catalyst $(0.227 \mathrm{~nm})$, illustrating the lattice contraction of Pd induced by the formation of PdIr alloy and the IrNi alloy core, in accordance with the XRD result. These evidences ascertain the formation of core-shell nanostructure consisting of IrNi alloy core and Pd-rich outer shell.

This core-shell nanostructure is further identified by the HAADF-STEM measurement and the EDS elemental mapping. The HAADF-STEM image of the CG Pd-Ir-Ni/C nanoparticle (Fig. 4a) shows a dense bright center and a thin dim peripheral, suggesting the formation of a coreshell nanostructure [48]. The EDS elemental mapping and corresponding overlapping images of $\mathrm{Ni}, \mathrm{Pd}$ and Ir (Fig. 4b-f) demonstrate that Ir and $\mathrm{Ni}$ atoms are mainly distributed in the center of the particle, while Pd is spread throughout the particle with an apparent enrichment in its concentration on the surface. Moreover, we have performed the EDS line scanning analysis to further illustrate the spatial distribution of the elements in a Pd-Ir-Ni/C nanoparticle (Fig. $4 \mathrm{~g}$ and 
4h). It is clearly shown that $\mathrm{Pd}$ is more distributed on the shell whereas $\mathrm{Ir}$ and $\mathrm{Ni}$ are mainly confined to the core region. These results definitely reveal the concentration gradient core shell structure of the $\mathrm{Pd}-\mathrm{Ir}-\mathrm{Ni} / \mathrm{C}$ catalyst.

The chemical composition of $\mathrm{IrNi} / \mathrm{C}$ and $\mathrm{CG}$ Pd-Ir-Ni/C samples is analyzed by the EDS spectra (Fig. S1 in Supporting Information). The bulk composition of the $\mathrm{IrNi} / \mathrm{C}$ catalyst is very close to the nominal value of 1:1 (Fig. S1a). The existence of Pd is confirmed by the EDS spectrum of CG Pd-Ir-Ni/C catalyst (Fig. S1b). It is interesting that the relative content of $\mathrm{Ni}$ decreases more apparently than $\mathrm{Ir}$ in the CG $\mathrm{Pd}-\mathrm{Ir}-\mathrm{Ni} / \mathrm{C}$ catalyst, suggesting the facile replacement of $\mathrm{Ni}$ by $\mathrm{Pd}$ during the deposition of $\mathrm{Pd}$ as a result of the spontaneous replacement reaction between $\mathrm{Pd}^{2+}$ and $\mathrm{Ni}[38,40]$.

XPS is employed to further investigate the surface composition and electronic properties of the CG Pd-Ir-Ni/C catalyst. Fig. 5 shows the wide range and detailed core level XPS spectra of $\mathrm{Pd} / \mathrm{C}, \mathrm{IrNi} / \mathrm{C}$ and $\mathrm{CG} \mathrm{Pd}-\mathrm{Ir}-\mathrm{Ni} / \mathrm{C}$ catalysts. It can be observed from the wide range spectra (Fig. 5a) that all the $\mathrm{Pd}$, Ir and $\mathrm{Ni}$ elements are detected in the surface region of $\mathrm{CG} \mathrm{Pd}-\mathrm{Ir}-\mathrm{Ni} / \mathrm{C}$ catalyst. The presence of Ir and Ni suggests that the Pd-shell is rather thin, since XPS reflects the composition of several layers beneath the outer most surface [21]. However, the intensity of the Ir $4 \mathrm{f}$ and $\mathrm{Ni} 2 \mathrm{p}$ peaks apparently decreases from $\mathrm{IrNi} / \mathrm{C}$ catalyst to $\mathrm{CG} \mathrm{Pd}-\mathrm{Ir}-\mathrm{Ni} / \mathrm{C}$ catalyst, and the content of Ir and Ni elements is much lower than that of Pd (Table 2), demonstrating that the surface is enriched by Pd. Meanwhile, the content of Ir is higher than that of Ni (Table 2), which confirms the displacement of more $\mathrm{Ni}$ atoms by $\mathrm{Pd}$ as described above. From the $\mathrm{Pd} 3 \mathrm{~d}$ core level XPS spectra (Fig. 5b and 5c), the deconvoluted Pd $3 \mathrm{~d}_{3 / 2}$ and Pd $3 \mathrm{~d}_{5 / 2}$ peaks in the CG Pd-Ir$\mathrm{Ni} / \mathrm{C}$ catalyst shift remarkably to higher binding energies than those in pure $\mathrm{Pd} / \mathrm{C}$ catalyst, while the $\operatorname{Ir} 4 \mathrm{f}_{7 / 2}$ and $\operatorname{Ir} 4 \mathrm{f}_{5 / 2}$ peaks shift to lower binding energies relative to $\mathrm{IrNi} / \mathrm{C}$ catalyst (Fig. $5 \mathrm{~d}$ 
and 5e). This shift illustrates the electronic interaction between surface Pd and underlying Ir, which should be mainly ascribed to the lattice strain effect because lattice strain is regarded as the major effect on electronic structure of core-shell nanoparticles [34]. The positive shift in the binding energy of surface Pd indicates the compressive lattice strain (decrease of Pd and Pd bond distance) induced by the Ir and Ni substrate with smaller lattice spacing $[41,42]$. For the Ni $2 p$ core level XPS spectra (Fig. 5f), the peaks at binding energies of $852.03 \mathrm{eV}$ and $869.23 \mathrm{eV}$ are assigned to the metallic $\mathrm{Ni}$, while those at $854.96 \mathrm{eV}$ and $872.19 \mathrm{eV}$ are attributed to $\mathrm{Ni}$ in the form of oxide or hydroxide $[40,44]$, which should be due to the oxidation of Ni exposed to air. It is revealed that $\mathrm{Ni}$ in the $\operatorname{IrNi} / \mathrm{C}$ catalyst exists prominently in the metallic $\left(\mathrm{Ni}^{0}\right)$ state and partially in the oxidized $\left(\mathrm{Ni}^{2+}\right)$ state. However, no apparent peaks of $\mathrm{Ni}$ can be observed for the CG Pd-Ir-Ni/C nanostructure, indicating the lower surface concentration of Ni. The results of XRD, HAADF-STEM, HRTEM, EDS and XPS collectively illustrate the formation of a CG PdIr-Ni/C core-shell electrocatalyst comprising $\mathrm{IrNi}$ alloy core and concentration gradient $\mathrm{IrPd}$ alloy shell.

The additional evidence for the Pd-rich surface of CG Pd-Ir-Ni/C catalyst can be obtained from the $\mathrm{CV}$ profiles in $\mathrm{N}_{2}$ saturated $0.1 \mathrm{M} \mathrm{HClO}_{4}$ solution shown (Fig. 6a). It is interesting to observe that the $\mathrm{CV}$ behavior of $\mathrm{CG}$ Pd-Ir-Ni/C catalyst is highly different from that of $\mathrm{IrNi} / \mathrm{C}$ catalyst, indicating a distinctive surface composition and structure. The resemblance in the shape of the hydrogen absorption/desorption peaks for CG Pd-Ir-Ni/C catalyst with that for $\mathrm{Pd} / \mathrm{C}$ catalyst illustrates a Pd-rich surface of CG Pd-Ir-Ni/C catalyst.

Fig. $6 \mathrm{~b}$ shows the linear sweep RDE polarization curves of the CG Pd-Ir-Ni/C catalyst at the rotation rates ranging from $400 \mathrm{rpm}$ to $1600 \mathrm{rpm}$ in $\mathrm{O}_{2}$ saturated $0.1 \mathrm{M} \mathrm{HClO}_{4}$ solution at scan rate of $5 \mathrm{mV} \mathrm{s}^{-1}$ in the potential window between +1.00 and $0.00 \mathrm{~V}$ vs. RHE. These RDE curves 
demonstrate well defined characteristic polarization regions for ORR, including the kinetic, mixed kinetic/diffusion and mass transfer controlled regions. It is observed that the limiting current density $\left(j_{\mathrm{d}}\right)$ in the potentials of $0.2 \mathrm{~V} \sim 0.7 \mathrm{~V}$ varies with the rotation rate $(\omega)$. The corresponding Koutecky-Levich (K-L) plots, derived from the polarization curves using the inverse of current density $(1 / j)$ as a function of the inverse of the square root of the rotation rate $\left(\omega^{-1 / 2}\right)$, are presented in Fig. 6c. The K-L plots are parallel straight lines, suggesting that the ORR on CG Pd-Ir-Ni/C catalyst follows first order kinetics with respect to molecular oxygen [39]. The ORR in acid media may take place through either a direct four-electron route involving the dissociation of oxygen molecules and its subsequent reduction to water, or an indirect peroxide pathway involving the formation of $\mathrm{H}_{2} \mathrm{O}_{2}$ as a final or intermediate product [1,2]. The number of electrons transferred per oxygen molecule on the CG Pd-Ir-Ni/C catalyst is calculated using the following Koutecky-Levich equation [19]:

$$
\begin{aligned}
& \frac{1}{j}=\frac{1}{j_{k}}+\frac{1}{B \omega^{1 / 2}} \\
& \mathrm{~B}=0.62 \mathrm{nFAD}_{\mathrm{O} 2}^{2 / 3} v^{-1 / 6} \mathrm{C}_{\mathrm{O} 2}
\end{aligned}
$$

where $\omega$ the rotation rate, $n$ the number of electrons transferred, $D_{\mathrm{O} 2}$ the diffusion coefficient of $\mathrm{O}_{2}\left(1.93 \times 10^{-5} \mathrm{~cm}^{2} \mathrm{~s}^{-1}\right), v$ the kinematic viscosity of the electrolyte $\left(1.01 \times 10^{-2} \mathrm{~cm}^{2} \mathrm{~s}^{-1}\right), C_{\mathrm{O} 2}$ the concentration of dissolved $\mathrm{O}_{2}$ in the electrolyte $\left(1.26 \times 10^{-6} \mathrm{~mol} \mathrm{~cm}^{-3}\right), F$ the Faraday constant $\left(96485 \mathrm{C} \mathrm{mol}^{-1}\right)$, and $A$ the electrode surface area $\left(0.196 \mathrm{~cm}^{-2}\right)$ [2]. The experimental $B$ value of the CG Pd-Ir-Ni/C catalyst, determined from the slope of Koutecky-Levich plots, is $8.78 \times 10^{-2}$ $\mathrm{mA} \mathrm{s}^{-1 / 2}$, which is very close to the theoretical value for a four-electron reduction of $\mathrm{O}_{2}(9.15 \times$ $10^{-2} \mathrm{~mA} \mathrm{~s}^{1 / 2}$ ). Specifically, the average number of electrons transferred for the CG Pd-Ir-Ni/C catalyst is 3.84 , which is only slightly lower than that of $\mathrm{Pt} / \mathrm{C}$ (3.96) calculated from the corresponding ORR polarization curves and K-L plots (Fig. S2 in Supporting Information). It is, 
therefore, clear that the ORR on CG Pd-Ir-Ni/C catalyst follows mainly a 4 electron pathway, which agrees with the Pd-based alloy catalysts [13,14].

The ORR activity of the CG Pd-Ir-Ni/C catalyst is compared to $\mathrm{Pd} / \mathrm{C}, \mathrm{IrNi} / \mathrm{C}$ and $\mathrm{Pt} / \mathrm{C}$ catalysts. Fig. 7a presents the ORR polarization curves of different catalysts in $\mathrm{O}_{2}$ saturated 0.1 $\mathrm{M} \mathrm{HClO}_{4}$ solution measured at the rotation speed of $1600 \mathrm{rpm}$. The current density is normalized to the geometric area of the working electrode $\left(0.196 \mathrm{~cm}^{2}\right)$. It can be seen that the ORR onset potential and half-wave potential $\left(E_{1 / 2}\right)$ vary for the different catalysts. The half-wave potential, which is often used to evaluate the ORR activity, increases in the sequence of $\mathrm{IrNi} / \mathrm{C}(708 \mathrm{mV})<$ $\mathrm{Pd} / \mathrm{C}(713 \mathrm{mV})<\mathrm{CG}$ Pd-Ir-Ni/C $(758 \mathrm{mV})<\mathrm{Pt} / \mathrm{C}(806 \mathrm{mV})($ Table 1). The CG Pd-Ir-Ni/C catalyst exhibits $45 \mathrm{mV}$ positive shift compared to $\mathrm{Pd} / \mathrm{C}$, indicating its enhanced ORR activity.

Fig. $7 \mathrm{~b}$ and $7 \mathrm{c}$ give the kinetic current densities of the as-prepared catalysts normalized to their corresponding mass of the noble metal (Pd or Ir) and total metal, respectively. The CG Pd$\mathrm{Ir}-\mathrm{Ni} / \mathrm{C}$ catalyst exhibits 5.6 times higher mass activity than $\mathrm{Pd} / \mathrm{C}$ catalyst at $0.80 \mathrm{~V}$. Furthermore, the mass activity with respective to the total metal loading for the $\mathrm{CG} \mathrm{Pd}-\mathrm{Ir}-\mathrm{Ni} / \mathrm{C}$ catalyst is also significantly higher than that of $\mathrm{Pd} / \mathrm{C}$. This activity is among the highest values in comparison with the Pd-based ORR catalysts reported in the literature. The mass activity of CG Pd-Ir-Ni/C catalyst at $0.8 \mathrm{~V}\left(55.1 \mathrm{~mA} \mathrm{mg}_{\mathrm{Pd}}{ }^{-1}\right)$ is significantly higher than that of ternary $\mathrm{PdFeCo} / \mathrm{C}$ alloy catalyst $\left(6.7 \mathrm{~mA} \mathrm{mg}_{\mathrm{Pd}}{ }^{-1}\right)$ [19]. Furthermore, the CG Pd-Ir-Ni/C catalyst exhibits the mass activity that is about 7 times that of $\mathrm{Ir}$ decorated $\mathrm{PdCu} / \mathrm{C}$ catalyst at $0.75 \mathrm{~V}$ [49]. This activity enhancement of the CG Pd-Ir-Ni/C catalyst should be attributed to the gradient core-shell nanostructure. As evidenced from the structural analyses, the CG Pd-Ir-Ni/C nanostructure consists of IrNi alloy core and gradient concentration Pd-rich outer surface. The smaller underlying $\mathrm{IrNi} / \mathrm{C}$ alloy core induces the compressive lattice strain. According to the d-band 
center theory [50-52], the compressive strain leads to an increase in the d-orbital overlap of surface Pd and broadens the $\mathrm{d}$-valence band, thereby lowering its $\mathrm{d}$-band center and valence energy. This, in turn, weakens the Pd-O interaction, facilitating efficient breakage of the O-O bond and allowing facile removal of oxygen containing intermediates, which enhances the ORR activity of the CG Pd-Ir-Ni/C catalyst. Actually, the mass activity of CG Pd-Ir-Ni/C catalyst is even comparable to that of $\mathrm{Pt} / \mathrm{C}$ catalyst at the typical operating fuel cell voltage $(\sim 0.7 \mathrm{~V})$ shown in the inset of Fig. 7a. However, it should also be noted that the ORR activity of CG Pd-Ir-Ni/C catalyst is lower than that of $\mathrm{Pt} / \mathrm{C}$ at higher potentials, which might be attributed to the lower onset potential of Pd based alloys than that of $\mathrm{Pt}$ [22] and the decrease in the amount of active metal sites at the surface due to the prominent oxidation of $\mathrm{Pd}$ at the higher potentials [14]. Meanwhile, the lowest ORR activity of the IrNi/C catalyst might be due to the binding of oxygen on its surface too firmly to allow efficient removal of the adsorbed reaction intermediates, which hinders further reaction steps and blocks the sites for $\mathrm{O}_{2}$ adsorption in the surface [12].

Methanol crossover from the anode to the cathode is one of the major problems in direct methanol fuel cells (DMFCs), which significantly reduces the performance of cathode ORR catalysts [52]. Fig. 8 presents the ORR polarization curves of $\mathrm{CG} \mathrm{Pd}-\mathrm{Ir}-\mathrm{Ni} / \mathrm{C}$ and $\mathrm{Pt} / \mathrm{C}$ catalysts in $\mathrm{O}_{2}$ saturated $0.1 \mathrm{M} \mathrm{HClO}_{4}$ solution with and without $1.0 \mathrm{M}$ methanol at a scan rate of $5 \mathrm{mV} \mathrm{s}^{-1}$ and rotation speed of $1600 \mathrm{rpm}$. It is intriguing to observe that the ORR activity of CG Pd-Ir$\mathrm{Ni} / \mathrm{C}$ catalyst is much higher than that of $\mathrm{Pt} / \mathrm{C}$ in the presence of methanol. Specifically, $1.0 \mathrm{M}$ methanol causes a $265 \mathrm{mV}$ negative shift in half wave potential of $\mathrm{Pt} / \mathrm{C}$ catalyst due to the competition between oxygen reduction and methanol oxidation reactions. In contrast, the same methanol results in only $9 \mathrm{mV}$ negative shift in half wave potential for the $\mathrm{CG} \mathrm{Pd}-\mathrm{Ir}-\mathrm{Ni} / \mathrm{C}$ catalyst, clearly illustrating its much higher methanol tolerance. Moreover, a large anodic peak is 
observed in the ORR curve of Pt/C catalyst in the presence of methanol, whereas no appreciable anodic current is detected for the CG Pd-Ir-Ni/C catalyst, signifying the significantly higher ORR selectivity of CG Pd-Ir-Ni/C catalyst than Pt/C catalyst. Therefore, the CG Pd-Ir-Ni/C catalyst is a promising cathode catalyst for DMFCs.

In addition to activity, the accelerated durability test (ADT) of the CG Pd-Ir-Ni/C and Pd/C catalysts is performed by potential cycling between 0.6 and $1.1 \mathrm{~V}$ in $\mathrm{N}_{2}$ saturated $0.1 \mathrm{M} \mathrm{HClO}_{4}$ solution at scan rate of $50 \mathrm{mV} \mathrm{s}^{-1}$. After the ADT test, the LSV curves of the CG Pd-Ir-Ni/C and $\mathrm{Pd} / \mathrm{C}$ catalysts for the ORR have been recorded and the results are shown in Fig. 9a and 9b. The half-wave potential of CG Pd-Ir-Ni/C catalyst shifts negatively by $21 \mathrm{mV}$, which is significantly lower than that of $\mathrm{Pd} / \mathrm{C}(35 \mathrm{mV})$. Moreover, the CG Pd-Ir-Ni/C catalyst shows a $42 \%$ loss in mass activity at $0.80 \mathrm{~V}$ after the ADT, which is much less than $\mathrm{Pd} / \mathrm{C}$ (63\% loss) (Fig. $8 \mathrm{c}$ and Table S1 in Supporting Information). The insets in Fig. 9a and 9b display the CV profiles for the CG Pd-Ir-Ni/C and $\mathrm{Pd} / \mathrm{C}$ catalysts in $\mathrm{N}_{2}$ saturated $0.1 \mathrm{M} \mathrm{HClO}_{4}$ solution before and after the ADT. The electrochemical surface area (ESA), which is determined from the integrated oxide reduction peaks before and after the stability test [19], decreases by $26 \%$ and $37 \%$ for the CG Pd$\mathrm{Ir}-\mathrm{Ni} / \mathrm{C}$ and $\mathrm{Pd} / \mathrm{C}$ catalysts, respectively (Table S1). TEM images of the CG Pd-Ir-Ni/C and $\mathrm{Pd} / \mathrm{C}$ catalysts are also compared before and after the ADT (Fig. S3 in Supporting Information). It can be clearly observed that the majority of CG Pd-Ir-Ni nanoparticles remain well dispersed on the carbon support after the ADT except a slight change in size (insets of Fig. S3b). However, a large aggregation is observed for $\mathrm{Pd} / \mathrm{C}$ nanoparticles with a wide range of particle distribution (insets of Fig. S3d). In addition, the EDS analysis of the CG Pd-Ir-Ni/C catalyst (Fig. S3e) after the ADT shows only a negligible composition change (Pd:Ir:Ni $=67: 29: 4)$ in comparison with the original CG Pd-Ir-Ni/C catalyst (Table 2). All these results reveal a better electrochemical 
stability of the CG Pd-Ir-Ni/C nanostructure, which is significantly higher than that of Pd based alloys reported in the literature $[21,38]$. This improvement in stability should be attributed to the gradient core-shell structure of the $\mathrm{CG} \mathrm{Pd}-\mathrm{Ir}-\mathrm{Ni} / \mathrm{C}$ catalyst, which prevents leaching of the alloying base metal (Ni) that usually causes catalyst degradation on potential cycling $[21,23]$.

\section{Conclusion}

A novel concept of concentration gradient (CG) core-shell nanostructured Pd-Ir-Ni catalyst is prepared by a facile sequential polyol method without any additional surfactant. This CG PdIr-Ni nanostructure consists of IrNi alloy core and Pd-rich outer surface, between which lies IrPd transition layer with gradient concentration of $\mathrm{Pd}$. The gradient $\mathrm{Pd}$ concentration is beneficial to reducing the $\mathrm{Pd}$ loading and thus the cost of fuel cell catalysts. More importantly, the electrocatalytic activity of Pd surface can be tuned by the underlying PdIr and IrNi alloys, which is ascribed to the strained lattice of Pd surface by the sublayer alloys with smaller lattice spacing as well as the larger surface area resulting from better nanoparticle dispersion. The resulting carbon supported CG Pd-Ir-Ni NPs (Pd-Ir-Ni/C) catalyst exhibits superior ORR activity, especially at relatively low potentials, in comparison to $\mathrm{Pd} / \mathrm{C}$ and even $\mathrm{Pt} / \mathrm{C}$ catalysts. Moreover, the CG Pd-Ir-Ni/C catalyst presents excellent ORR selectivity in the presence of methanol, which is significantly better than the commercial Pt/C catalyst. Therefore, our CG Pd-Ir-Ni/C nanostructure is a promising low cost and high performance ORR catalyst, in particular for direct type fuel cells, and this concept can also be extended to other electrocatalytic materials.

\section{Acknowledgments}

This work was supported by the National Science Foundation of China under contract No. 21376057 and 21433003. 


\section{References}

[1] M. Gattrell, B. MacDougall, Hand book of fuel cells-Fundamentals, Technology and Applications, John Wiley \& Sons, UK, 2010.

[2] C. Song, J. Zhang, Hand book of PEM fuel cell Electrocatalysts and catalyst layers, London, 2008.

[3] H. Liu, D. Xia, J. Zhang, Hand book of PEM fuel cell Electrocatalysts and catalyst layers, London, 2008.

[4] H. Wendt, Quim. Nova, Vol. 28, No.6, 2005, pp.1066.

[5] I.E.L. Stephens, A. S. Bondarenko, U. Grønbjerg, J. Rossmeisl, I. Chorkendorff, Energy Environ. Sci. 5 (2012) 6744.

[6] D. Thompsett, Hand book of fuel cells-Fundamentals, Technology and Applications, John Wiley \& Sons, UK, 2010.

[7] J.H. Hirschenhofer, D.B. Stauffer, R.R. Engleman, M.G. Klett, Fuel cells Hand book, $4^{\text {th }}$ ed., 1998.

[8] A. Brouzgou, S.Q. Songb, P. Tsiakaras, Applied Catalysis B: Environmental 127 (2012) 371.

[9] K. Lee, L. Zhang, J. Zhang, Hand book of fuel cells-Fundamentals, Technology and Applications, John Wiley \& Sons, UK, 2010.

[10] B. Viswanathan, Ch. Venkateswara Rao, U. V. Varadaraju, Energy and Fuel (2006) 43.

[11] E. Antolini, Energy Environ. Sci. 2 (2009) 915.

[12] M. Shao, P. Liu, J. Zhang, R.R. Adzic, J. Phys. Chem. B 111 (2007) 6772.

[13] M. Shao (ed.), Electrocatalysis in Fuel Cells, Lecture Notes in Energy 9, Springer-Verlag London, 2013. 
[14] N. Alexeyeva, A. Sarapuu, K. Tammeveski, F.J. Vidal-Iglesias, J. Solla-Gullonb, J.M. Feliu, Electrochim Acta 56 (2011) 6702.

[15] L. Arroyo-Ramírez, R. Montano-Serrano,T. Luna-Pineda, F. R. Román, R. G. Raptis, C. R. Cabrera, ACS Appl. Mater. Interfaces 5 (2013) 11603.

[16] K. Oishi, O. Savadogo, J. Electroanal. Chem. 703 (2013) 108.

[17] X. Wang, N. Kariuki, J. T. Vaughey, J. Goodpaster, .R. Kumar, D. J. Myers, ECS 155 (2008) B602.

[18] W.Tang, L. Zhang, G. Henkelman, J. Phys. Chem. Lett. 2 (2011)1328.

[19] K. Mohanraju, L. Cindrella, RSC Adv. 4 (2014) 11939.

[20] J. Mathiyarasu, K. L. N. Phani, ECS, 154 (2007) B1100.

[21] J. Zhao, A. Sarkar, A. Manthiram, Electrochim Acta 55 (2010) 1756.

[22] D. Wang, H.L. Xin, H. Wang, Y.Yu, E. Rus, D.A. Muller, F.J. DiSalvo, H.D. Abruna, Chem. Mater. 24 (2012) 2274.

[23] H.C. Ham, D. Manogaran, K. H. Lee, K. Kwon, Seon-ah Jin, D. J. You, C. Pak, G. S. Hwang, J. Chem. Phys. 139 (2013) 1.

[24] F.I. Pires, H.M. Villullas, Int. J. Hydrogen energy 37 (2012) 17052.

[25] S. Stolbov, M. A. Ortigoza, J. Phys. Chem. Lett. 3 (2012) 463.

[26] J. Luo, L. Wang, D. Mott, P. N. Njoki, Y. Lin, T. He, Z. Xu, B. N. Wanjana, I.-Im S. Lim, C- Zhong, Adv. Mater. 20 (2008) 4342.

[27] Q. Zhang, I. lee, J.B. Joo, F. Zaera, Y. Yin, Acc. Chem. Research 10 (2012) 1.

[28] S.J. Hwang, S.J. Yoo, J. Shin, Y-H. Cho, J.H. Jang, E. Cho, Y-E. Sung, S.W. Nam, T-H. Lim, S-C. Lee, S-K. Kim, Nat. Sci. Reports 3 (2013) 1.

[29] R. Huang, Y-H. Wen, Z-Z. Zhu, S-G. Sun, J. Phys. Chem. C 116 (2012) 8664. 
[30] X. Zhang, G. Lu, J. Phys. Chem. Lett. 5 (2014) 292.

[31] K. Sasaki, H. Naohara, Y. Choi, Y. Cai, W-F. Chen, P. Liu, R.R. Adzic, Nat. Commun. 3 (2012) 1115.

[32] Q. Tan, C. Du, G. Yin, P. Zuo, X. Cheng, M. Chen, J. Catal. 295 (2012) 217.

[33] E. Antolini, J.R.C. Salgado, M.J. Giz, E.R. Gonzalez, Int. J. Hydrogen Energy 30 (2005) 1213.

[34] P. Strasser, S. Koh, T. Anniyev, J. Greeley, K. More, C. Yu, Z. Liu, S. Kaya, D. Nordlund, H. Ogasawara, M.F. Toney, A. Nilsson, Nat. Chem. 623 (2010) 1.

[35] M. Oezaslan, F.d. Hasche, P. Strasser, J. Phys. Chem. Lett. 4 (2013) 3273.

[36] X. Wang, B. He, Z. Hu, Z. Zeng, S. Han, Sci. Technol. Adv. Mater. 15 (2014) 043502.

[37] R.R. Adzic, Electrocatalysis, Springer Science + Business Media, LLC2012.

[38] T. Cochell, A. Manthiram, Langmuir 28 (2012) 1579.

[39] W. Wang, R. Wang, S. Ji, H. Feng, H. Wang, Z. Lei, J. Power Sources 195 (2010) 3498.

[40] H. Wang, D. Cao, Y. Xiang, D. Liang, S. Lu, RSC Adv. 4 (2014) 51126.

[41] J. Yang, X. Chen, X. Yang, J. Y. Ying, Energy Environ. Sci. 5 (2012) 8976.

[42] J. Yang, X. Chen, F. Ye, C. Wang, Y. Zheng, J. Yang, J. Mater. Chem. 21 (2011) 9088.

[43] S. Liao, B. Li, Y. Li, Hand book of PEM fuel cell Electrocatalysts and catalyst layers, London, 2010.

[44] X-Z. Fu, Y. Liang, S-P. Chen, J-D. Lin, D-W. Liao, Catal. Commun. 10 (2009) 1893.

[45] X. Li, J. Liu, W. He, Q. Huang, H. Yang, J. Colloid Interface Sci. 344 (2010) 132

[46] T. Hyde, Platinum Metals Rev. 52 (2008) 129.

[47] J. Chen, Y. Li, Z. Gao, G.Wang, J. Tian, C. Jiang, S. Zhu, R.Wang, Electrochem. Commun. 37 (2013) 24. 
[48] X. Zhao, S. Chen, Z. Fang, J. Ding, W. Sang, Y. Wang, J. Zhao,Z. Peng, J. Zeng, J. Am. Chem. Soc. 137 (2015) 2804.

[49] D. J. You, S. Jin, K. H. Lee, C. Pak, K. H. Choi, H. Chang, Catal. Today 185 (2012) 138.

[50] M. Mavrikakis, B.Hammer, J.K. Norskov, Phys. Review Lett. 81 (1998) 2819.

[51] B. Hammer, L.B. Hansen, J.K. Norskov, Phys. Review B 59 (1999) 7413.

[52] M.H. Shao, K. Sasaki, R. R. Adzic, J. Am. Chem. Soc. 128 (2006) 3526. 
Table $1 \mathrm{XRD}$ and electrochemical results of the as-prepared catalysts

\begin{tabular}{|c|c|c|c|c|c|}
\hline \multirow{2}{*}{ Sample } & \multirow{2}{*}{$\begin{array}{l}\text { Crystallite } \\
\text { size (nm) }\end{array}$} & \multirow{2}{*}{$\begin{array}{l}\text { Lattice } \\
\text { parameter } \\
(\mathbf{n m})\end{array}$} & \multirow{2}{*}{$\begin{array}{c}E_{1 / 2} \\
(\mathrm{mV})\end{array}$} & \multicolumn{2}{|c|}{$\begin{array}{c}\text { Mass activities }\left(\mathrm{mA} \mathrm{mg}^{-1}\right) \\
\text { at } 0.80 \mathrm{~V}\end{array}$} \\
\hline & & & & (Pd/Ir) & (Total Metal) \\
\hline $\mathrm{Pd} / \mathrm{C}$ & 8.4 & 0.39223 & 713 & 9.93 & 9.93 \\
\hline $\mathrm{IrNi} / \mathrm{C}$ & 4.6 & 0.37973 & 708 & 3.07 & 2.31 \\
\hline $\begin{array}{l}\text { CG Pd-Ir- } \\
\mathrm{Ni} / \mathrm{C}\end{array}$ & 6.7 & 0.38875 & 758 & 55.11 & 31.14 \\
\hline
\end{tabular}

Table 2 Chemical composition of IrNi/C and CG Pd-Ir-Ni/C catalysts determined by EDS and XPS (wt\%)

\begin{tabular}{ccccccc}
\hline & \multicolumn{3}{c}{ IrNi/C } & \multicolumn{3}{c}{ CG Pd-Ir-Ni/C } \\
\cline { 2 - 7 } element & Nominal & EDS & XPS & Nominal & EDS & XPS \\
\hline Pd & 0 & 0 & 0 & 56.10 & 68.50 & 74.52 \\
Ir & 76.80 & 80.50 & 81.91 & 33.60 & 24.70 & 21.58 \\
Ni & 23.20 & 19.50 & 18.09 & 10.30 & 06.80 & 03.90 \\
\hline
\end{tabular}




\section{Figure Captions}

Scheme 1 Schematic illustration of the synthesis of concentration gradient Pd-Ir-Ni nanostructure.

Fig. 1 XRD patterns of $\mathrm{Pd} / \mathrm{C}, \mathrm{Ir} / \mathrm{C}, \mathrm{IrNi} / \mathrm{C}$ and $\mathrm{CG}$ Pd-Ir-Ni/C catalysts (a), and enlarged (111) peak of $\mathrm{Pd} / \mathrm{C}, \mathrm{IrNi} / \mathrm{C}$ and $\mathrm{CG} \mathrm{Pd}-\mathrm{Ir}-\mathrm{Ni} / \mathrm{C}$ catalysts (b).

Fig. 2 TEM images and corresponding particle size distribution histograms of $\mathrm{Pd} / \mathrm{C}$ (a and $b$ ), $\mathrm{IrNi} / \mathrm{C}$ (c and d) and CG Pd-Ir-Ni/C (e and f) catalysts.

Fig. 3 High resolution TEM images of $\mathrm{Pd} / \mathrm{C}$ (a) and CG Pd-Ir-Ni/C (b) catalysts.

Fig. 4 High-angle annular dark field scanning TEM (HAADF-STEM) image of CG Pd-Ir-Ni/C nanoparticle (a), the corresponding elemental maps of $\mathrm{Ni}, \mathrm{Pd}$ and $\mathrm{Ir}$ (b, c, d), overlapped elemental maps of Ir and $\mathrm{Ni}(\mathrm{e})$ and of Ni, Ir and Pd (f), HAADF-STEM image of a CG Pd-Ir$\mathrm{Ni} / \mathrm{C}$ nanoparticle $(\mathrm{g})$ and elemental line scan profile of $\mathrm{Ni}$, Ir and $\mathrm{Pd}(\mathrm{h})$ along the line marked in image (g).

Fig. 5 Wide range XPS spectra of $\mathrm{Pd} / \mathrm{C}, \mathrm{IrNi} / \mathrm{C}$ and CG Pd-Ir-Ni/C catalysts (a), Pd 3d core level XPS spectra of CG Pd-Ir-Ni/C and Pd/C catalysts (b and c), Ir 4f core level XPS spectra of CG Pd-Ir-Ni/C and IrNi/C catalysts ( $\mathrm{d}$ and e) and Ni 2 p core level XPS spectra of CG Pd-Ir-Ni/C and $\mathrm{IrNi} / \mathrm{C}$ catalysts (f).

Fig. 6 (a) Cyclic voltammograms of Pd/C, IrNi/C and CG Pd-Ir-Ni/C catalysts recorded at a scan rate of $50 \mathrm{mV} \mathrm{s}^{-1}$ in $\mathrm{N}_{2}$ saturated $0.1 \mathrm{M} \mathrm{HClO}_{4}$ solution, (b) polarization curves for ORR on the CG Pd-Ir-Ni/C catalyst at a scan rate of $5 \mathrm{mV} \mathrm{s}^{-1}$ in $\mathrm{O}_{2}$ saturated $0.1 \mathrm{M} \mathrm{HClO}_{4}$ solution at different rotation rates, and (c) the corresponding Koutecky-Levich plots at different potentials. 
Fig. 7 (a) Linear sweep voltammograms of $\mathrm{Pd} / \mathrm{C}, \mathrm{IrNi} / \mathrm{C}, \mathrm{CG}$ Pd-Ir-Ni/C and $\mathrm{Pt} / \mathrm{C}$ catalysts measured at a scan rate of $5 \mathrm{mV} \mathrm{s}^{-1}$ and rotation speed of $1600 \mathrm{rpm}$ in $\mathrm{O}_{2}$ saturated $0.1 \mathrm{M} \mathrm{HClO}_{4}$ solution, and (b) Pd/Ir metal and (c) total metal mass activities $\left(\mathrm{mA} \mathrm{mg}^{-1}\right)$ of $\mathrm{Pd} / \mathrm{C}, \mathrm{IrNi} / \mathrm{C}$ and CG Pd-Ir-Ni/C catalysts obtained at different potentials $(0.80 \mathrm{~V}, 0.84 \mathrm{~V}$ and $0.88 \mathrm{~V})$. Inset: $\mathrm{Pd} / \mathrm{Pt}$ metal mass activities ( $\mathrm{A} \mathrm{mg}^{-1}$ ) of CG Pd-Ir-Ni/C and as-prepared Pt/C catalysts at $0.69,0.71$ and $0.73 \mathrm{~V}$.

Fig. 8 Linear sweep voltammograms of CG Pd-Ir-Ni/C and Pt/C catalysts before and after the addition of $1.0 \mathrm{M} \mathrm{CH}_{3} \mathrm{OH}$ into $\mathrm{O}_{2}$ saturated $0.1 \mathrm{M} \mathrm{HClO}_{4}$ electrolyte solution at scan rate of 5 $\mathrm{mV} \mathrm{s}^{-1}$ and rotation speed of $1600 \mathrm{rpm}$.

Fig. 9 Linear sweep voltammograms of (a) CG Pd-Ir-Ni/C and (b) $\mathrm{Pd} / \mathrm{C}$ catalysts recorded in $\mathrm{O}_{2}$ purged $0.1 \mathrm{M} \mathrm{HClO}_{4}$ solution before and after the ADT (Insets: the corresponding cyclic voltammograms in $0.1 \mathrm{M} \mathrm{HClO}_{4}$ solution before and after the ADT), and (c) the kinetic mass activities $\left(\mathrm{mA} \mathrm{mg}_{\mathrm{Pd}}{ }^{-1} @ 0.8 \mathrm{~V}\right.$ ) of the CG Pd-Ir-Ni/C and $\mathrm{Pd} / \mathrm{C}$ catalysts before and after the ADT. 


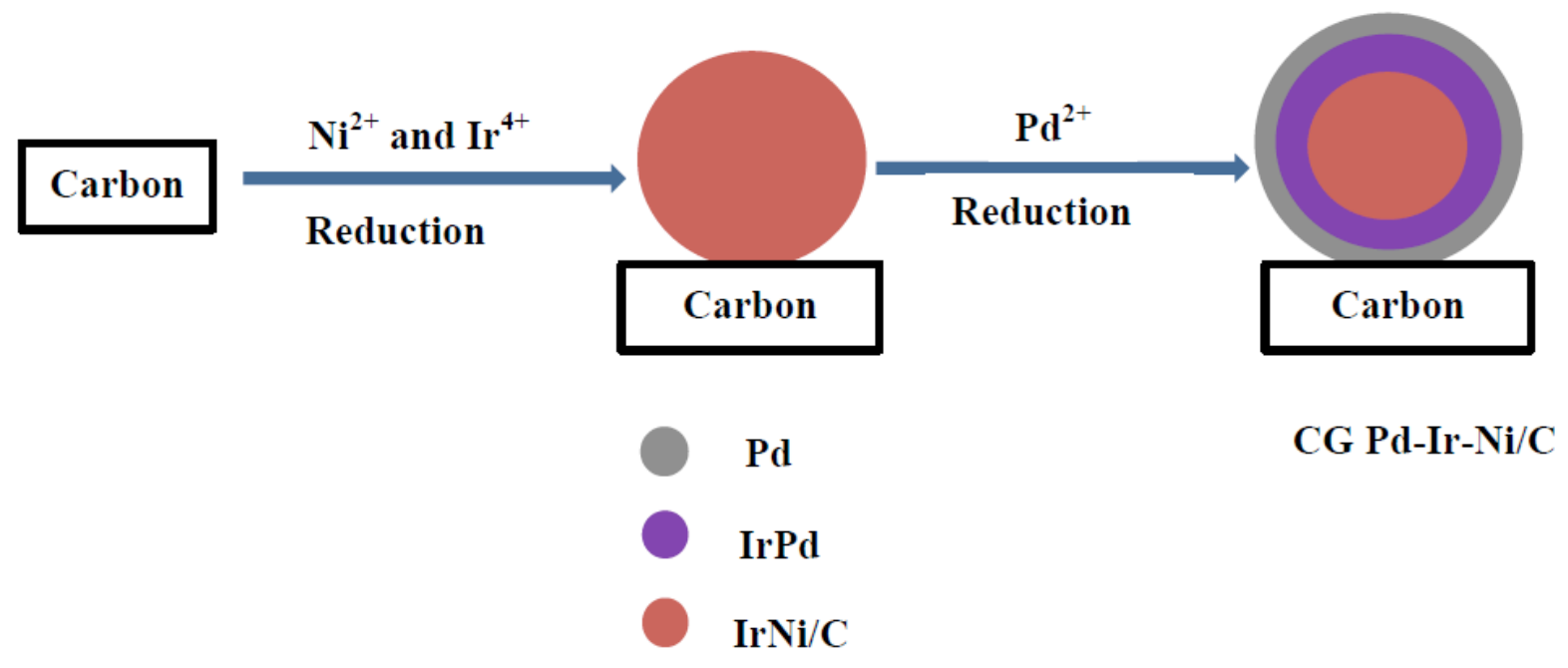

Scheme 1 

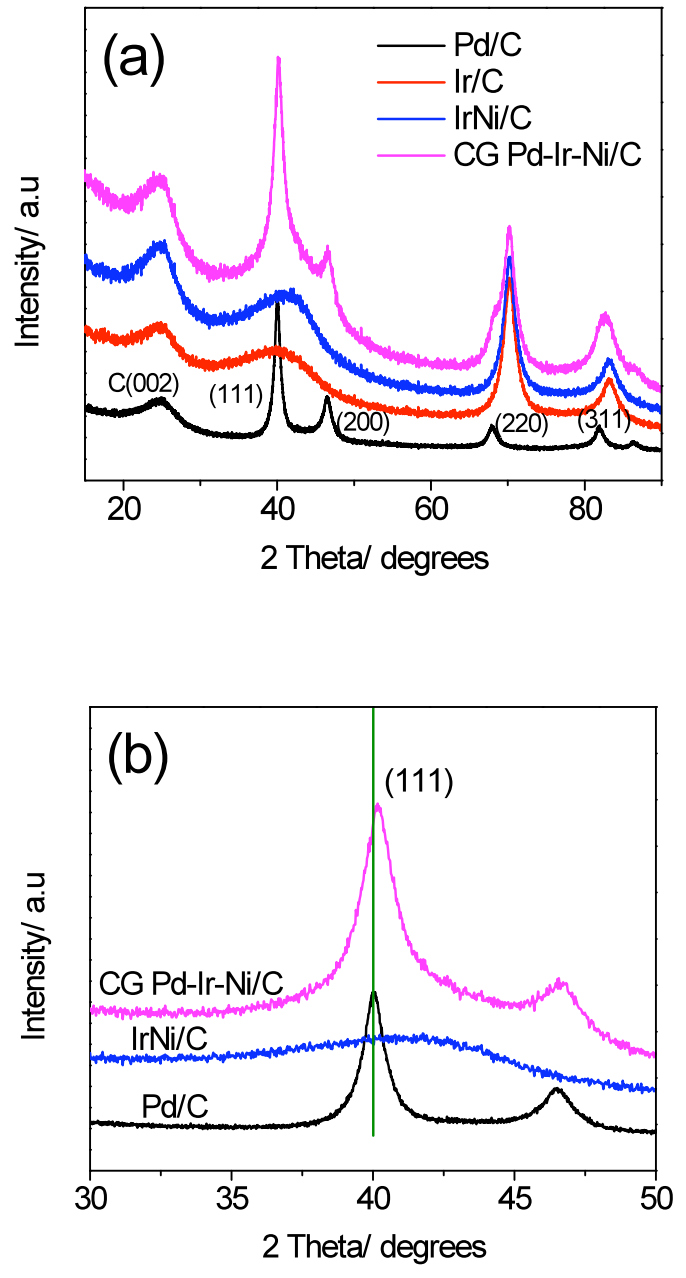

Fig.1 

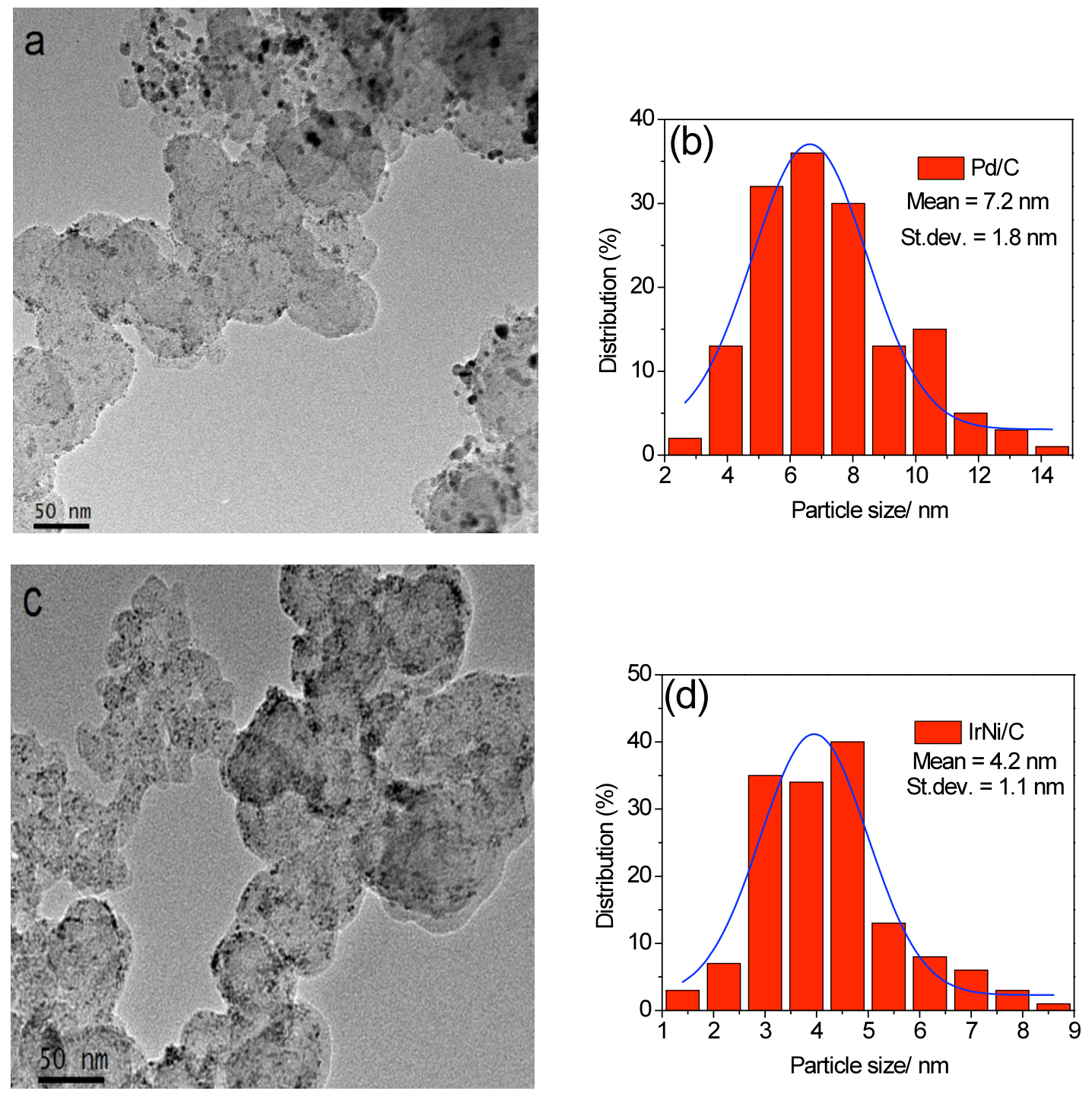

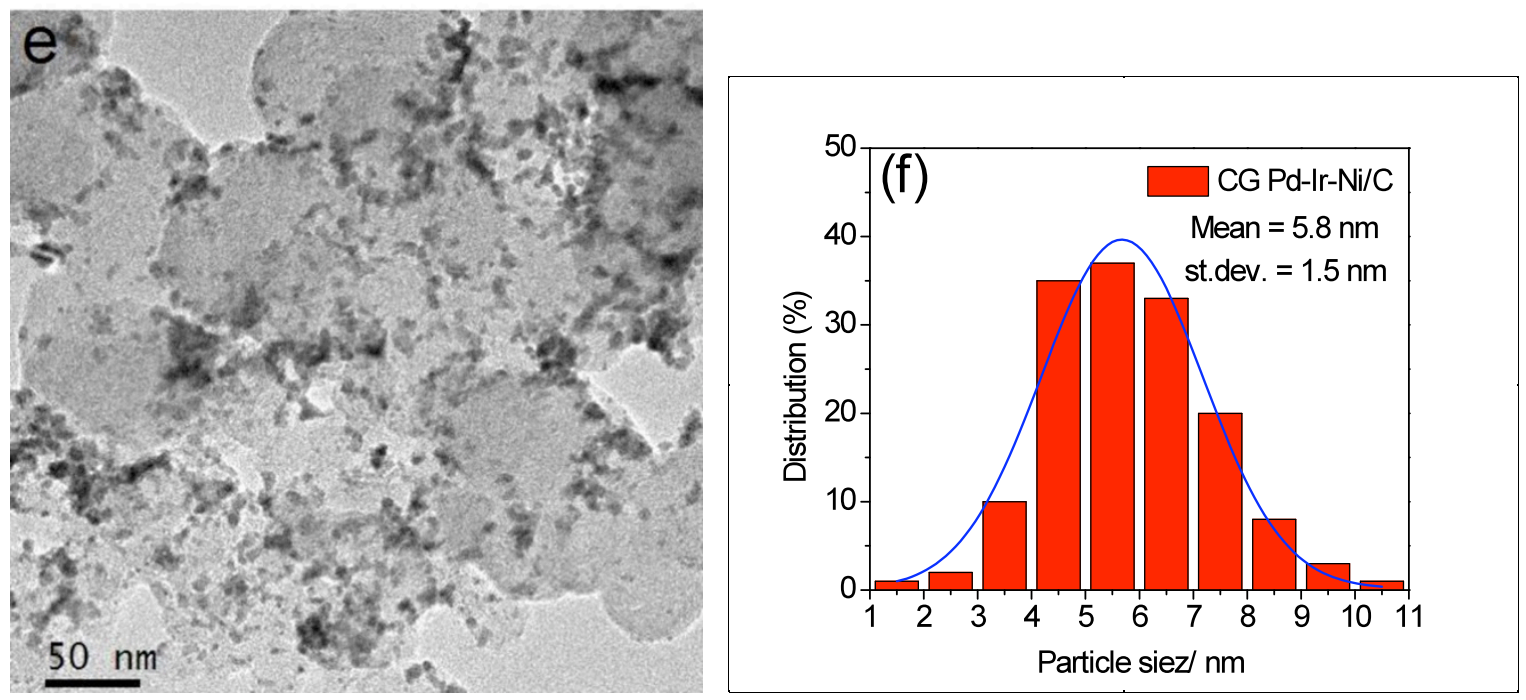

Fig.2
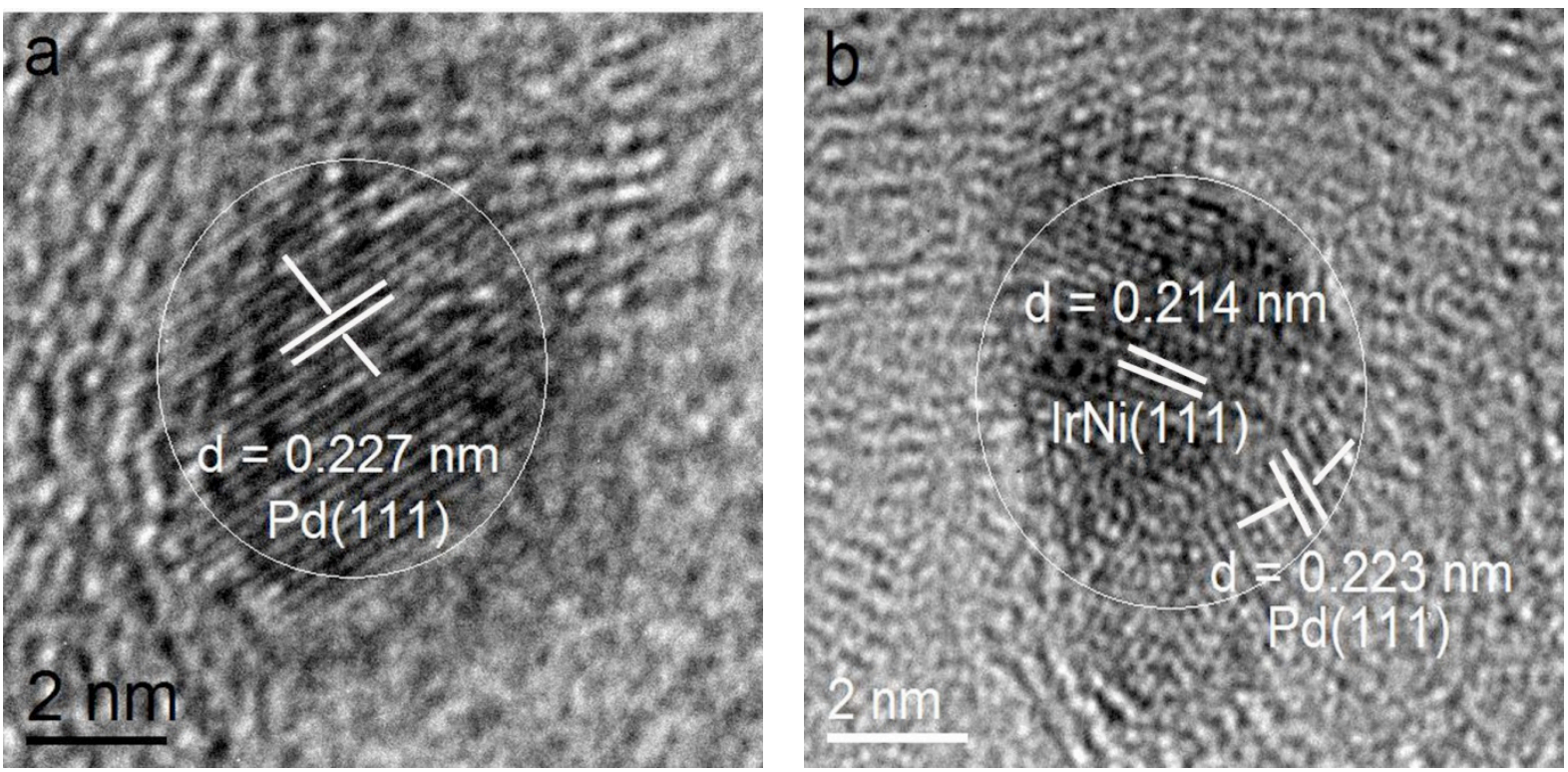
Fig.3
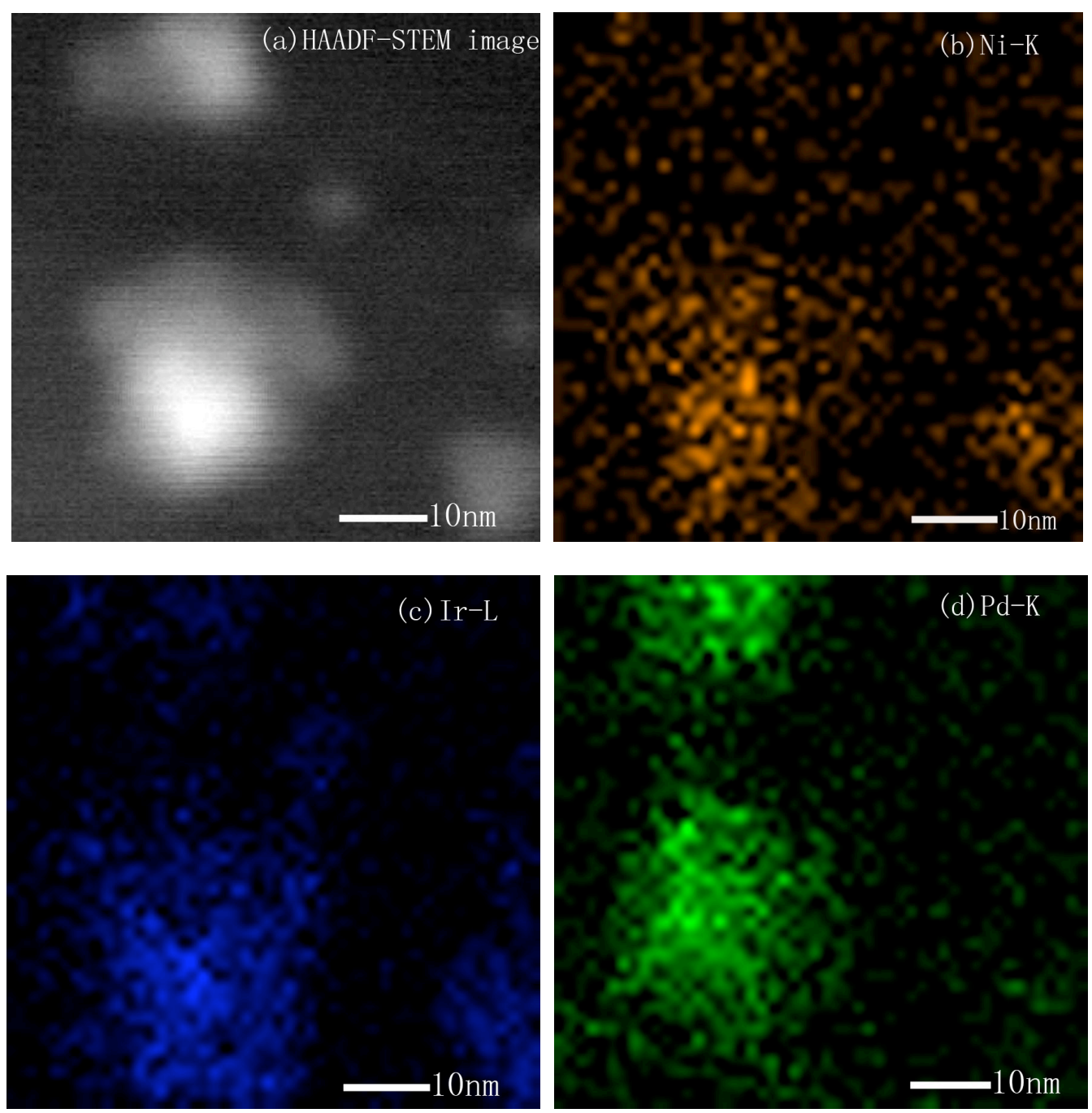

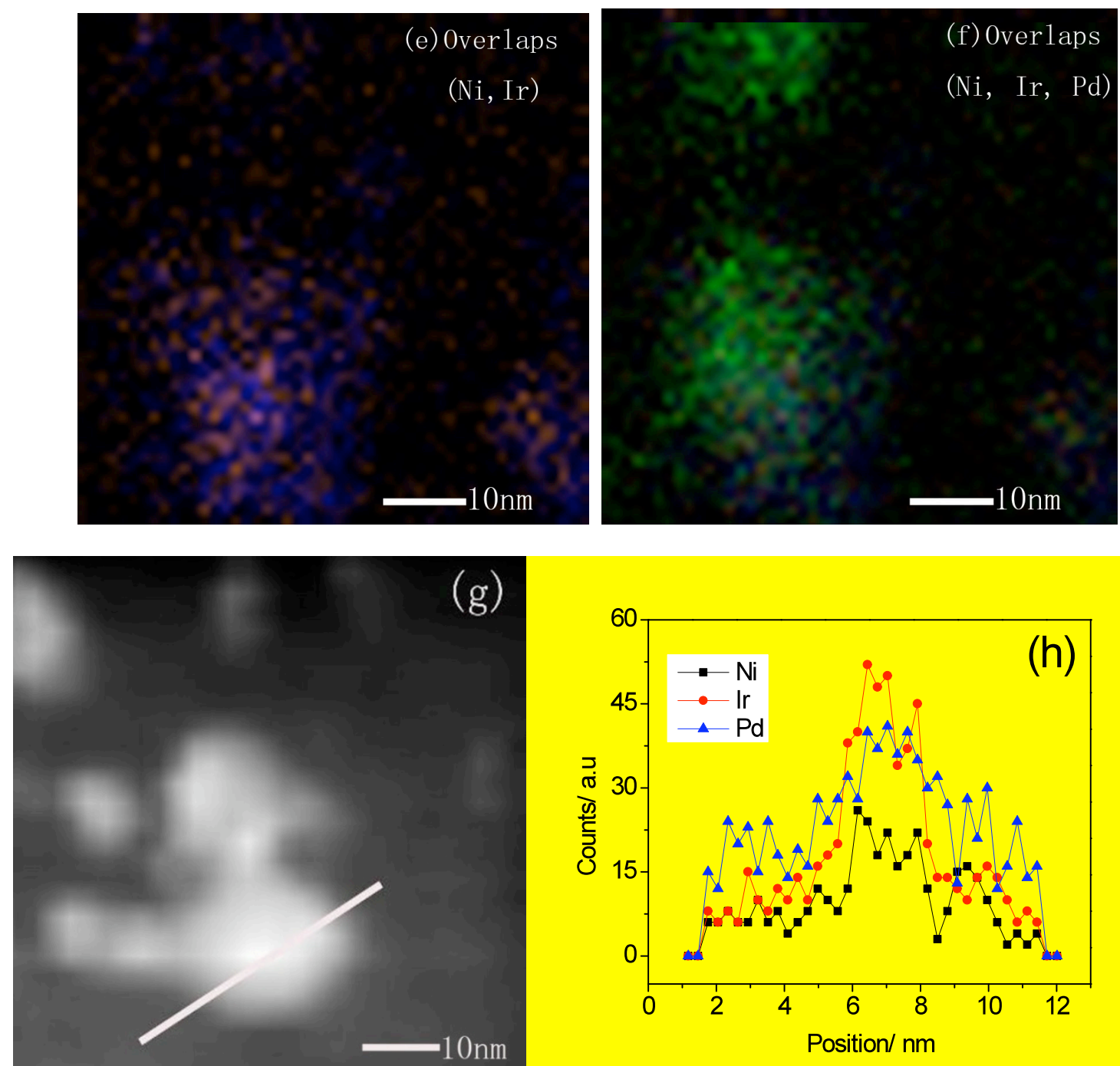

Fig.4 

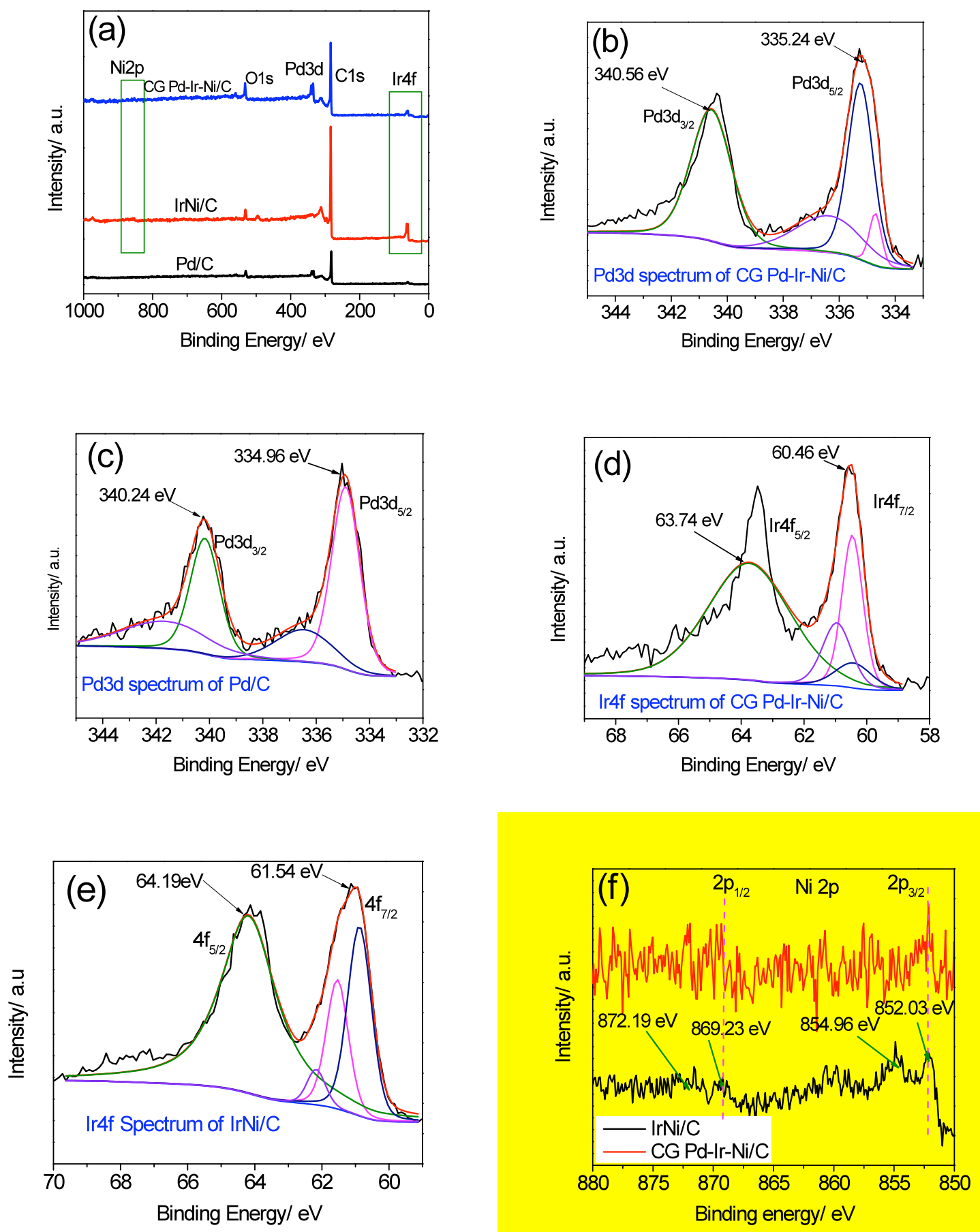
Fig.5
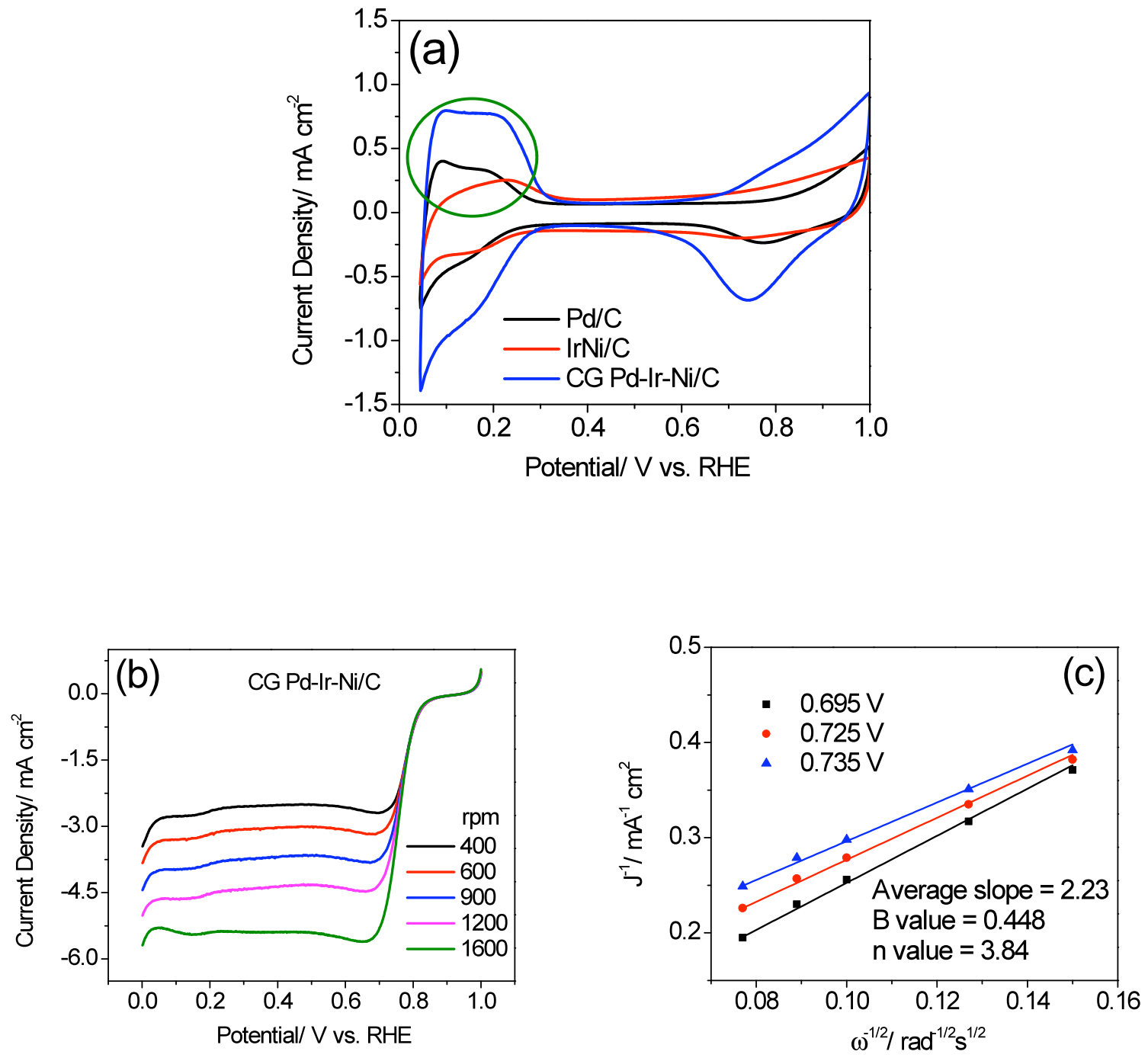

Fig. 6 

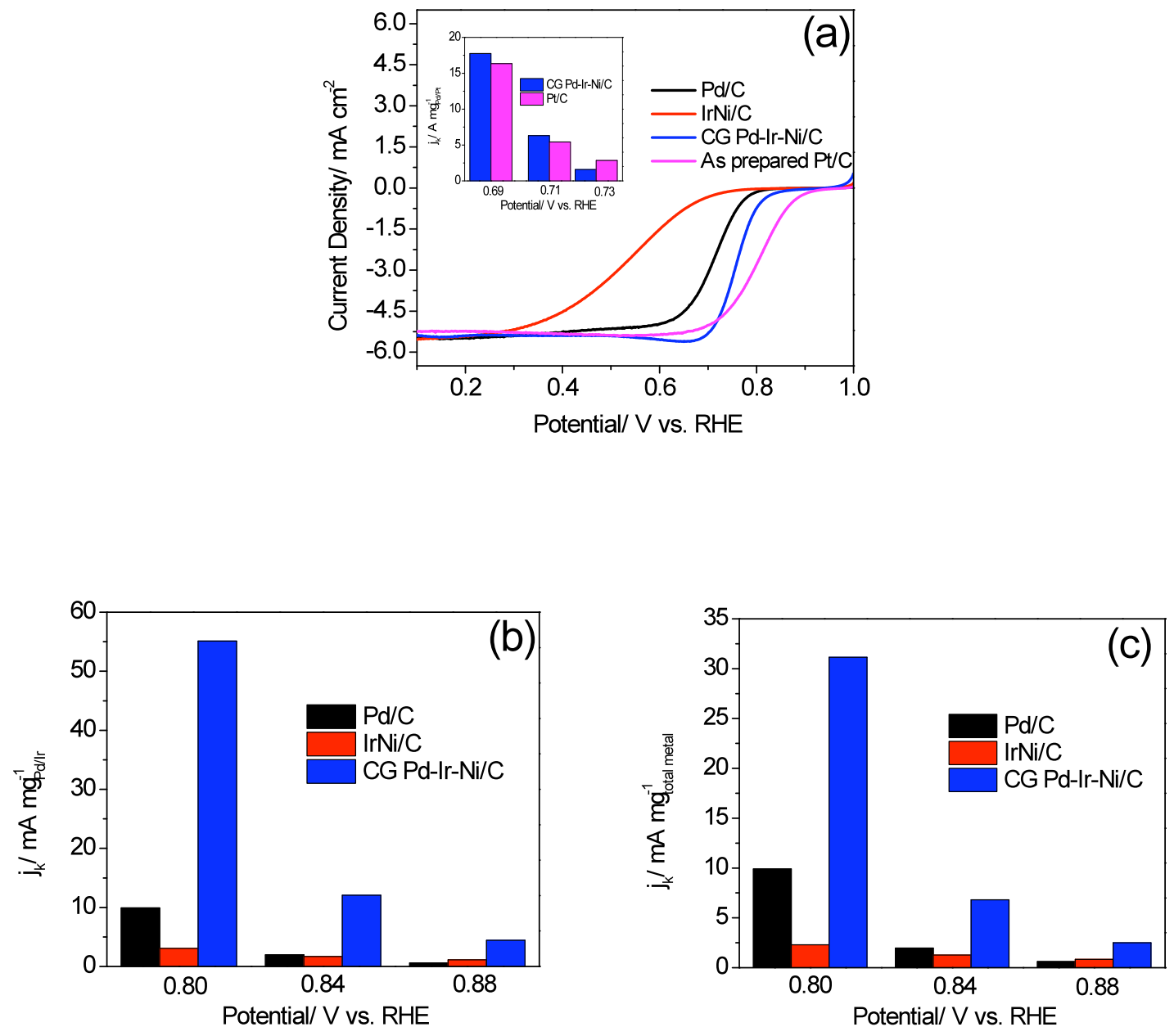

Fig. 7 


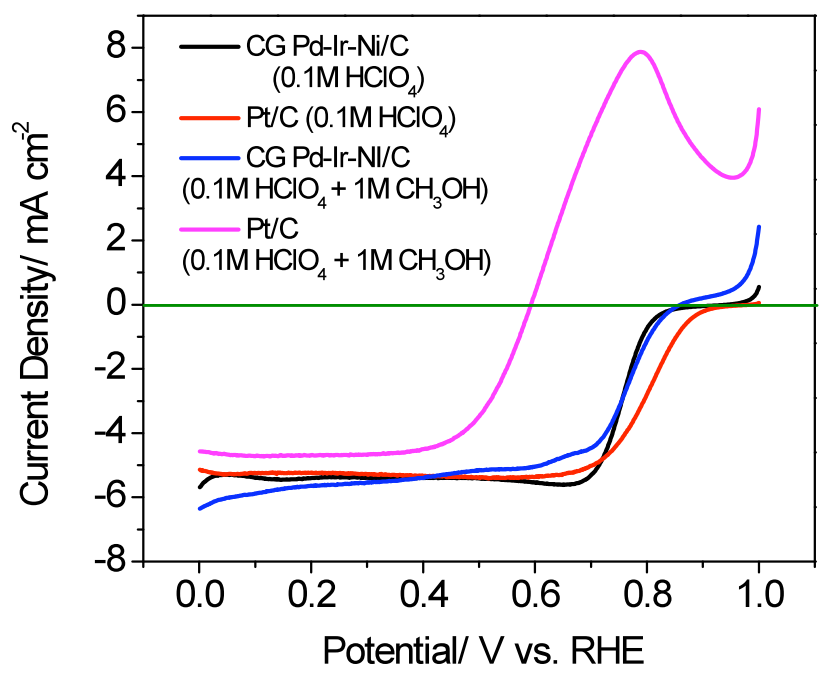

Fig. 8 

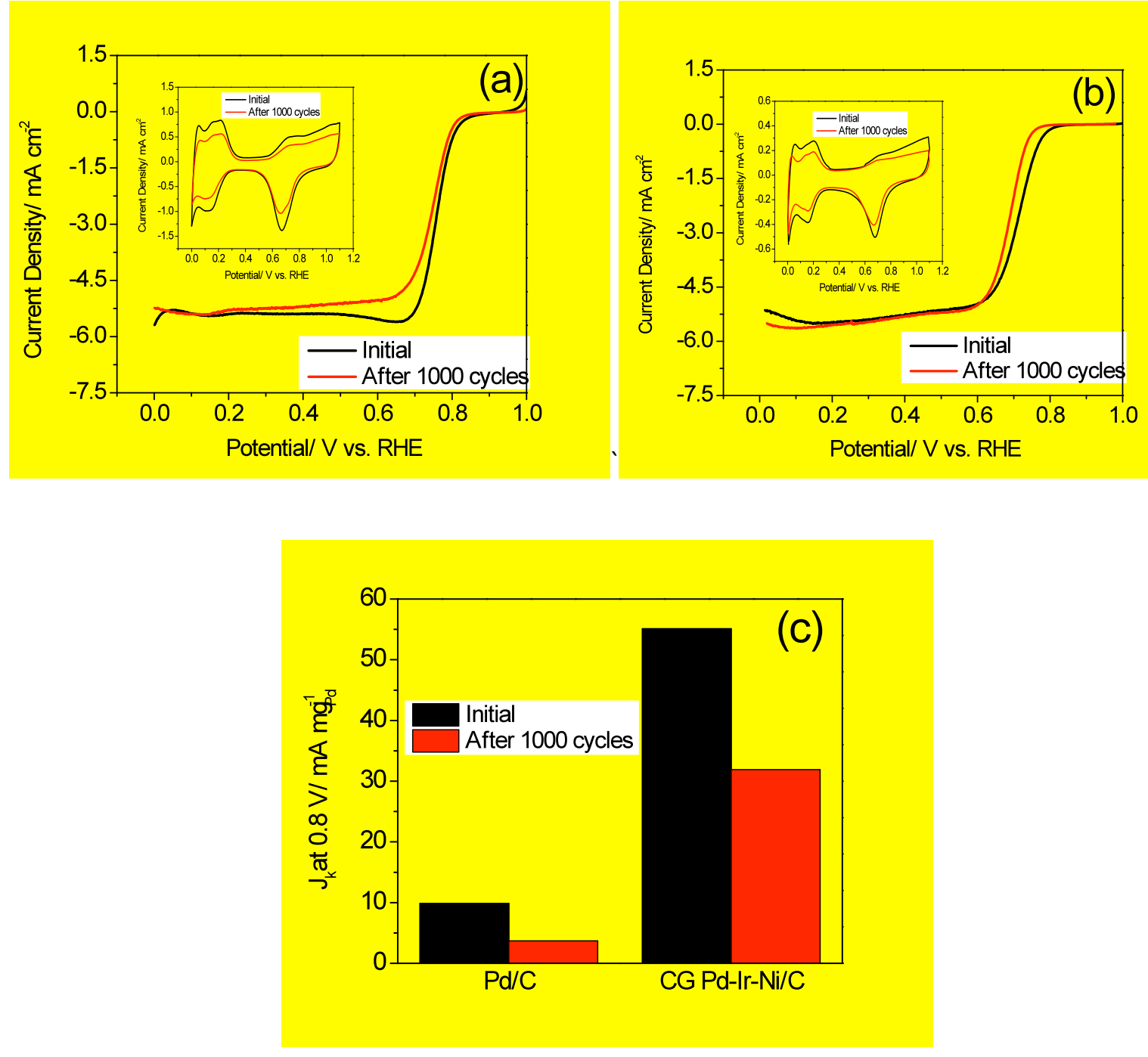

Fig. 9 